\title{
Kajian:
}

Pembelajaran PPKn

\section{PERAN SERIKAT PEREMPUAN INDEPENDEN (SPI) LABUHANBATU DAN DINAS PEMBERDAYAAN PEREMPUAN DAN PERLINDUNGAN ANAK (DPPPA) TERHADAP KORBAN KEKERASAN PEREMPUAN DAN ANAK DI KABUPATEN LABUHANBATU TAHUN 2017-2018}

${ }^{1}$ Nurhanipah, ${ }^{2}$ Khairul Fahmi Lubis, MSP

Program Studi Pendidikan Pancasila dan Kewarganegaraan

STKIP Labuhanbatu, Jl.SM Raja No126 A, Rantauprapat

Email: nurhanipah222@gmail.com,khairulfahmilubis@gmail.com

\begin{abstract}
Abstrak
Penelitian ini bertujuan untuk mengetahui Peran Serikat Perempuan Independen (SPI) Labuhanbatu dan Dinas Pemberdayaan Perempuan dan Perlindungan Anak (DPPPA) Terhadap Korban Kekerasan Perempuan dan Anak Di Kabupaten Labuhanbatu Tahun 20172018. Penelitian ini menggunakan metode kualitatif dengan pendekatan deskriptif. Peneliti memilih jenis penelitian ini karena peneliti bermaksud menggambarkan, menjelaskan kasuskasus yang terdapat dalam masalah penelitian ini secara kompleks. Teknik pengumpulan yang digunakan yaitu wawancara dan observasi dijadikan sebagai sumber data primer sedangkan dokumentasi dijadikan sebagai sumber data sekunder. Dari data yang peneliti peroleh dari Serikat Perempuan Independen (SPI) Labuhanbatu kekerasan terhadap perempuan dan anak ditahun 2017 yaitu 74 kasus dan ditahun 2018 yaitu 56 kasus. Sedangkan data yang peneliti peroleh dari Dinas Pemberdayaan Perempuan dan Perlindungan Anak (DPPPA) Kabupaten Labuhanbatu kekerasan terhadap perempuan dan anak ditahun 2017 yaitu 71 kasus dan ditahun 2018 yaitu 61 kasus. Hasil penelitian menunjukkan bahwa peran Serikat Perempuan Independen (SPI) Labuhanbatu yaitu memberikan penguatan pendampingan terhadap korban kasus kekerasan terhadap perempuan dan anak, sedangkan Peran Dinas Pemberdayaan Perempuan dan Perlindungan Anak (DPPPA) Kabupaten Labuhanbatu yaitu dengan cara memberikan perlindungan terhadap korban kekerasan terhadap perempuan dan anak.
\end{abstract}

Kata Kunci: Serikat Perempuan, Perlindungan, Korban Kekerasan 


\section{Kajian:}

Pembelajaran PPKn

\section{PENDAHULUAN}

Kasus kekerasan terhadap anak sering terjadi di lingkungan masyarakat. Anak dan perempuan adalah manusia yang mempunyai kemampuan fisik, mental dan sosial yang dianggap lebih lemah untuk mengatasi berbagai resiko dan bahaya yang dihadapinya dan secara otomatis masih bergantung pada pihak-pihak lain terutama anggota keluarga yang berperan aktif untuk melindungi dan memeliharanya. Kekerasan terhadap perempuan dan anak merupakan tindakan pelanggaran HAM yang paling kejam.

Dari data yang saya peroleh dari kantor Serikat Perempuan Independen dan Dinas Pemberdayaan Perempuan dan Perlindungan Anak, Kasus kekerasan di Labuhanbatu pada tahun 2017-2018 sangat memprihatinkan khususnya untuk perempuan dan anak. Adapun data yang saya peroleh untuk mengetahui seberapa banyak kasus-

JOMAS

Vol. 1 No. 1 Januari (2019)

$$
\text { Hal : } 1-8
$$

kasus yang terjadi dilabuhanbatu yaitu sebagai berikut:

Tabel 1.1 Data Kasus Kekerasan SPI Tahun 2017-2018

\begin{tabular}{|c|c|c|c|}
\hline \multirow{2}{*}{ No } & \multirow{2}{*}{$\begin{array}{c}\text { Jenis } \\
\text { Kekerasan }\end{array}$} & \multicolumn{2}{|c|}{ Tahun } \\
\cline { 3 - 4 } 1 & $\begin{array}{c}\text { Kekerasan } \\
\text { Dalam Rumah } \\
\text { Tangga }\end{array}$ & $\begin{array}{c}69 \\
\text { Kasus }\end{array}$ & $\begin{array}{c}51 \\
\text { Kasus }\end{array}$ \\
\hline 2 & $\begin{array}{c}\text { Kekerasan } \\
\text { Seksual }\end{array}$ & $\begin{array}{c}5 \\
\text { Kasus }\end{array}$ & $\begin{array}{c}5 \\
\text { Kasus }\end{array}$ \\
\hline
\end{tabular}

\begin{tabular}{|c|c|c|c|}
\hline 3 & Total Jumlah & $\begin{array}{c}74 \\
\text { Kasus }\end{array}$ & $\begin{array}{c}56 \\
\text { Kasus }\end{array}$ \\
\hline
\end{tabular}

Sumber: Serikat Perempuan Independen Labuhanbatu

Dari data yang saya peroleh dari anggota SPI Labuhanbatu ternyata kasuskasus pada anak dan perempuan di Labuhanbatu pada tahun 2017 berjumlah 74 kasus sedangkan di tahun 2018 berjumlah 56 kasus. Sehingga upaya yang di lakukan oleh SPI Labuhanbatu dalam menangani kasus kekerasan adalah memberikan pencegahan, penanganan, dan pemulihan dengan cara bersosialisasi kemasyarakat melalui suatu perkumpulan seperti, perwiritan, remaja masjid dan lainlain.

Adapun yang menyebabkan korban mengalami tindak kekerasan baik itu perempuan maupun anak yaitu karena Kemajuan teknologi yang semakin pesat teknologi yang seharusnya menjadi media yang bernilai positif, Kurangnya perekonomian dalam keluarga, Adanya pemakaian narkoba, Broken home, Kurang kasih sayang.

Adapun dampak berdasarkan bentuk kekerasan yang dialami korban, dapat membawa dampak negatif sebagai berikut yaitu:

a. Secara fisik kekerasan ini mengakibatkan adanya kerusakan tubuh seperti: luka-luka memar, luka-luka simetris di wajah (di kedua sisi), punggung, tungkai, luka lecet, sayatan, luka bakar. 


\section{Kajian:}

Pembelajaran PPKn

b. Secara psikis, perempuan dan anak yang mengalami penganiayaan pada umumnya menunjukkan: penarikan diri, ketakutan atau bertingkah laku agresif, emosi yang labil, depresi, jati diri yang rendah, kecemasan, adanya gangguan tidur, ketakutan, kelak bisa tumbuh menjadi penganiaya, menjadi bersifat keras.

Harapan saya sebagai peneliti dengan adanya SPI Labuhanbatu dan Dinas Pemberdayaan Perempuan dan Perlindungan Anak (DPPPA) Kabupaten Labuhanbatu, dengan program-program yang mereka miliki bisa membantu masyarakat ataupun korban agar terhindar dari kekerasan yang dilakukan oleh orangorang terdekatnya.

Dengan adanya Lembaga-lembaga Pemberdayaan Perlindungan perempuan dan anak di Kabupaten Labuhanbatu ini diharapkan dapat membantu kasus-kasus yang melibatkan perempuan dan anak sebagai korban kekerasan.

Berdasarkan latar belakang masalah di atas, maka penulis tertarik melakukan penelitian dengan judul "Peran

Serikat Perempuan Independen (SPI) Labuhanbatu dan Dinas Pemberdayaan Perempuan dan Perlindungan Anak (DPPPA) Terhadap Korban Kekerasan Perempuan dan Anak Di Kabupaten Labuhanbatu Tahun 2017-2018"

\section{Pengertian Peran}

Miftah Thoha dalam jurnal Winata (2018) yang berjudul Peran Lembaga
Pemberdayaan Masyarakat Kelurahan Dalam Memberdayakan Masyarakat mengatakan bahwa Peran adalah suatu rangkaian yang teratur yang ditimbulkan karena suatu jabatan. Manusia sebagai makhluk sosial memiliki kecenderungan untuk hidup berkelompok. Dalam kehidupan berkelompok tadi akan terjadi interaksi antara anggota masyarakat yang satu dengan anggota masyarakat yang lainnya. Tumbuhnya interaksi diantara mereka ada saling ketergantungan. Dalam kehidupan bermasyarakat itu munculah apa yang dinamakan peran (role).

Berdasarkan dari beberapa pengertian tersebut apabila dihubungkan dengan Pemberdayaan perempuan dan anak, penulis menyimpulkan bahwa peran adalah tindakan

JOMAS

Vol. 1 No. 1 Januari (2019)

$$
\text { Hal : } 1-8
$$

berupa serangkaian usaha-usaha dan kegiatan yang dijalankan oleh SPI karena kedudukannya sebagai gerakan organisasi publik diharapkan dapat memberikan pengaruh pada anggota serta masyarakat sesuai dengan tujuan Pemberdayaan perempuan dan anak.

\section{Serikat Perempuan Independen}

SPI merupakan organisasi massa perempuan perdesaan yang wilayah kerjanya berada di Sumatera Utara, yang berdiri pada tanggal 21 Oktober 2001, beranggotakan kelompok-kelompok 


\section{Kajian:}

Pembelajaran PPKn

perempuan perdesaan dari berbagai macam latar belakang.

SPI Labuhanbatu tidak berdiri sendiri sejarah SPI merupakan kelompok-kelompok kecil yang anggotanya berasal dari desa. SPI Labuhanbatu terbentuk dari Himpunan Serikat Perempuan Indonesia (HAPSARI) dimana hapsari melatih kelompok-kelompok yang menjadi organisasi diserikatnya, jadi SPI adalah salah satu dari anggotanya. Ibu Istuti Laili Lubis merupakan ketua SPI Labuhanbatu pada tahun 2015-2020.

Sebagian besar pengurus dan anggota-anggota di SPI Labuhanbatu adalah perempuan yang mengalami kekerasan dalam rumah tangga, yang kemudian mampu mengatasinya dan menjadi pembela bagi perempuan korban yang lain.

\section{Fungsi Serikat Perempuan Independen}

Adapun fungsi yang terdapat didalam organisasi SPI Labuhanbatu yaitu:

1. Mewujudkan wadah perjuangan bersama kaum perempuan melalui organisasi-organisasi perempuan yang independen untuk menegakkan keadilan sosial dan kesetaraan gender, mengalokasikan kepentingan kasus terhadap perempuan dan anak perempuan korban kekerasan.

2. Memfasilitasi serta mendorong tumbuhnya organisasi-organisasi perempuan perdesaan yang akan memperjuangkan upaya penegakan dan penghormatan terhadap hak-hak kaum perempuan terutama bagi anggota, Penguatan keorganisasian memberikan ataupun mencukupi fasilitas dan bagaimana kelompokkelompok bekerjasama untuk membangun organisasi yang mereka jalani.

3. Membangun mekanisme kerja organisasi dan kepemimpinan kaum perempuan perdesaan yang lebih demokratis dan independen.

4. Penguatan ekonomi bagi penggerak perempuan melakukan pelatihan ekonomi berupa kerajinan ataupun kuliner untuk pemasukan perekonomian keluarga.

\section{Tugas Serikat Perempuan Independen}

Adapun tugas dari SPI

Labuhanbatu yaitu sebagai berikut:

1. Mengadvokasikan atau mengakseskan layanan-layanan terhadap perempuan kekerasan secara gratis pada korban kekerasan.

2. Pendampingan kasus.

3. Mendorong atau mengajak pemerintah membuat peraturan dan kebijakan.

\section{Pemberdayaan Perempuan dan Anak}




\section{Kajian:}

Pembelajaran PPKn

Menurut Suyono dalam Ruslan (2010) Upaya pemberdayaan perempuan dan anak pada khususnya dan pemberdayaan manusia pada umumnya, adalah salah satu topik yang paling banyak mendapat perhatian berbagai kalangan. Pemberdayaan perempuan dan anak sering pula disebut sebagai peningkatan kualitas hidup personal perempuan, yakni suatu upaya untuk memberdayakan kehidupan perempuan dalam berbagai bidang, termasuk ekonomi, pendidikan, sosial, komunikasi, informasi, dan lain sebagainya

JOMAS

Vol. 1 No. 1 Januari (2019)

$$
\text { Hal : } 1-8
$$

agar mereka terbebas dari belenggu kemiskinan dan keterbelakangan.

Berdasarkan dari beberapa pengertian tersebut apabila dihubungkan dengan Pemberdayaan perempuan dan anak, penulis menyimpulkan bahwa suatu bentuk untuk meningkatkan partisipasi dalam kehidupan masyarakat dapat bersosialisasi sehingga mampu menjadi individu-individu yang bermanfaat bagi siapapun.

\section{Pengertian Kekerasaan}

Richard dalam Skripsi Rahma Diani Sormin (2017) yang berjudul Partisipasi Pusat Pelayanan Terpadu Pemberdayaan Perempuan dan Anak Lamban Indoman Putri Dalam Penanganan Kekerasan Terhadap Anak di Provinsi Lampung mengatakan bahwa kekerasan terhadap anak adalah perbuatan yang di sengaja yang menimbulkan kerugian atau bahaya terhadap anak-anak secara fisik maupun emosional. Istilah kekerasan anak mencakup beberapa perilaku, dari serangan fisik atau pengasuh dewasa lain untuk mengabaikan kebutuhan dasar anak.

Berdasarkan penjelasan tersebut apabila dihubungkan dengan Pemberdayaan perempuan dan anak dapat diartikan bahwa, kekerasan merupakan suatu bentuk perlakuan kasar yang dialami oleh perempuan dan anak sehingga menimbulkan rasa sakit secara fisik maupun psikis, pelaku kekerasan yang dialami oleh korban adalah orangorang terdekat disekitar mereka.

\section{Bentuk-Bentuk Kekerasan}

1. Kekerasaan Fisik menunjuk pada cedera yang ditemukan pada seorang anak dan perempuan bukan karna suatu kecelakaan tetapi cedera tersebut adalah hasil dari pemukulan dengan benda atau beberapa penyerangan yang diulang-ulang.

2. Pengabaian Fisik kategori kekerasaan ini dapat didefenisikan secara umum dari kelesuan seorang anak dan perempuan, kepucatan dan dalam keadaan kurang gizi. Anak itu biasanya dalam keadaan kotor/tidak sehat, pakaian tidak memadai, dan kesehatan yang tidak memadai. Namun hal ini juga harus dilihat dari keadaan sosial ekonomi dari suatu keluarga. 


\section{Kajian:}

Pembelajaran PPKn

1. Kekerasaan Emosional dan Pengabaian Menunjuk pada kasus dimana orang tua/wali gagal untuk menyediakan lingkungan yang penuh cinta kasih kepada seorang anak untuk bisa bertumbuh, belajar, dan berkembang.

2. Kekerasan Seksual Kekerasan seksual menunjuk pada setiap aktivitas seksual. Bentuk kekerasan ini dapat berupa penyerangan atau tanpa penyerangan. termaksud kategori penyerangan apabila seorang anak menderita cedera fisik dan trauma emosional yang luar biasa. Dalam Kategori kekerasan seksual tanpa penyerangan anak tidak mengalami cedera fisik tetap saja menderita trauma emosional.

\section{Dinas Pemberdayaan Perempuan dan Perlidungan Anak}

Dinas Pemberdayaan Perempuan dan Perlindungan Anak Kabupaten Labuhanbatu secara umum mempunyai tugas dan fungsi melaksanakan penyusunan dan pelaksanaan kebijakan daerah dibidang pemberdayaan perempuan dan perlindungan anak Kabupaten Labuhanbatu, penanganan korban kekerasan terhadap anak sehingga terpenuhinya hak dan perlindungan bagi korban yang mendapatkan kekerasan. Sesuai dengan kebijakan yang ditetapkan oleh Bupati berdasarkan peraturan perundangundangan yang berlaku.
Dalam pemenuhan hak-hak anak tersebut maka pemerintah melakukan upaya melalui intansi yang mempunyai tugas dan fungsi yang langsung berhubungan dengan

JOMAS

Vol. 1 No. 1 Januari (2019)

$$
\text { Hal : } 1-8
$$

perlindungan anak. Dinas Pemberdayaan Perempuan dan Perlindungan Anak Kabupaten Labuhanbatu (DPPPA) memiliki tugas dan fungsi yang erat kaitannya dengan perlindungan terhadap hak-hak anak diKabupaten Labuhanbatu. Dinas Pemberdayaan Perempuan dan Perlindungan Anak (DPPPA) Kabupaten Labuhanbatu dibentuk dalam rangka meningkatkan kesejahteraan masyarakat, merumuskan strategi perlindungan anak melalui upaya-upaya pemberian perlindungan, menyelenggarakan pembinaan umum dan koordinasi di bidang kesetaraan gender, bidang perlindungan perempuan dan anak, bidang data dan informasi. Adapun visi dan misi Dinas Pemberdayaan Perempuan dan Perlindungan Anak (DPPPA) Kabupaten Labuhanbatu sebagai berikut :

Visi : "Mewujudnya layanan prima korban Kekerasan Terhadap Perempuan dan Anak (KTPA)"

Misi : Membentuk pengembangan jejaringan yang profesional dan berkualitas dalam memberikan perlindungan dan rasa aman dengan 


\section{Kajian:}

Pembelajaran PPKn

pendekatan berwawasan gender bagi korban Kekerasan Terhadap Perempuan dan Anak (KTPA) melalui layanan yaitu: Medis, Konseling, Pendampingan hukum, Penyediaan rumah aman.

\section{Faktor-Faktor Penghambat Dinas Pemberdayaan Perempuan Dan Perlindungan Anak}

Adapun faktor-faktor

penghambat dalam pelaksanaan pengawasan tersebut adalah sebagai berikut :

1. Sarana dan Prasarana

2. Sumber daya manusia

3. Masyarakat

\section{Kerangka Pemikiran}

Untuk memberikan arahan pada pelaksanaan penelitian, maka kerangka konseptual yang akan dijadikan arahan bagi penelitian adalah sebagai berikut:

Uma Sekaran dalam Sugiyono (2014) Kerangka berfikir adalah suatu model konseptual tentang bagaimana teori berhubungan dengan berbagai faktor yang diidentifikasikan sebagai masalah yang penting.

Kerangka pikir digunakan untuk memudahkan penelitian ini dalam mencari jawaban dalam permasalahan yang telah dirumuskan dan perlu penjabaran secara konkret dalam kerangka teoritis agar mudah dipahami. Agar tidak terjadi salah pengertian maka terlebih dahulu penulis menentukan kerangka pikir untuk mengetahui peran konselor dalam menangani kasus korban tindak kekerasan anak dan perempuan.

\section{METODE PENELITIAN}

\section{a. Tempat dan Waktu Penelitian}

Tempat penelitian adalah Kantor Serikat Perempuan Independen (SPI) Labuhanbatu dan Dinas Pemberdayaan Perempuan dan Perlindungan Anak (DPPPA) Kabupaten Labuhanbatu. Waktu penelitian yang direncanakan untuk melakukan penelitian ini adalah pada tanggal 1 April 2019-11 April 2019.

\section{b. Pendekatan dan Jenis Penelitian}

Jenis penelitian yang digunakan dalam penelitian ini adalah jenis penelitian kualitatif dengan pendekatan deskriptif.

Peneliti memilih jenis penelitian ini karena peneliti bermaksud menggambarkan, menjelaskan dan mendeskripsikan kasus-kasus yang terdapat dalam masalah penelitian ini secara kompleks. Melalui pendekatan deskriptif, peneliti bermaksud untuk menemukan, memahami dan menjelaskan tentang peran yang dilakukan Serikat Perempuan Independen (SPI) Labuhanbatu dan Dinas Pemberdayaan Perempuan Dan Perlindungan Anak (DPPPA) Terhadap Korban Kekerasan Perempuan dan Anak di Kabupaten Labuhanbatu serta menganalisisnya dengan rinci berdasarkan informasi dan informan.

JOMAS 


\section{Kajian:}

Pembelajaran PPKn

Vol. 1 No. 1 Januari (2019)

Hal : $1-8$

\section{c. Sumber Data}

Sugiyono (2013), sumber data utama dalam penelitian kualitatif ialah manusia sebagai peneliti, memilih informan sebagai sumber data. Sumber data merupakan suatu benda, hal atau orang maupun tempat yang dapat dijadikan sebagai acuan peneliti untuk mengumpulkan data yang diinginkan sesuai dengan masalah dan fokus penelitian. Jenis data yang dikumpulkan melalui penelitian ini meliputi:

\section{d. Data Primer}

Menurut Sugiyono (2013), data primer merupakan data yang diperoleh secara langsung dari informan atau objek penelitian. Dalam penelitian ini data yang bisa saya dapatkan dari Dinas Pemberdayaan Perempuan dan Perlindungan Anak (DPPPA) Kabupaten Labuhanbatu adalah sebagai berikut:

Tabel 3.1 Data Kasus Kekerasan DPPPA Tahun 2017-2018

\section{e. Data Sekunder}

Menurut Sugiyono (2013), data sekunder merupakan data yang diperlukan dalam penelitian untuk melengkapi informasi dari data primer. Data sekunder merupakan sumber data tidak langsung memberikan data kepada peneliti atau misalnya melalui orang lain atau melalui dokumen.

\section{Prosedur Penelitian}

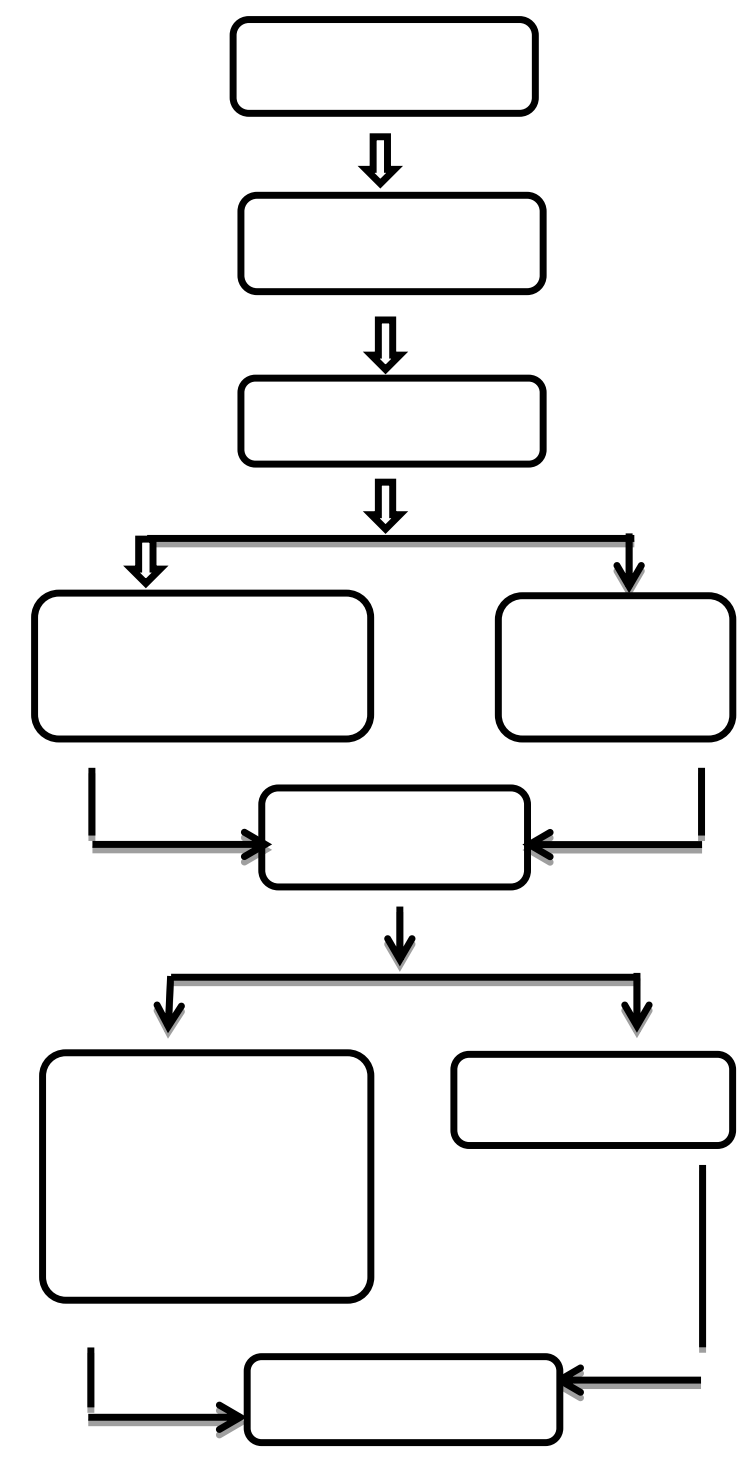

\section{a. Subjek}

Adapun informan dalam penelitian diperoleh dari kunjungan lapangan ke lokasi penelitian oleh peneliti, yakni Kantor Serikat Perempuan Independen (SPI) Labuhanbatu dan Dinas Pemberdayaan Perempuan dan 


\section{Kajian:}

Pembelajaran PPKn

Perlindungan Anak (DPPPA) Kabupaten Labuhanbatu.

\section{b. Objek}

Dalam metode ini beberapa objek penelitian dipilih, kemudian dari yang terpilih sebagai narasumber yaitu Serikat Perempuan Independen (SPI) Labuhanbatu dan Dinas Pemberdayaan Perempuan dan Perlindungan Anak (DPPPA) Kabupaten Labuhanbatu.

Dengan kata lain metode pengambilan sampel yang digunakan dengan teknik informan kunci (key informan) yaitu peneliti mengambil orang-orang kunci yang untuk dijadikan sebagai sumber data.

\section{Teknik pengumpulan Data}

\section{a. Observasi \\ b. Wawancara \\ c. Dokumentasi}

\section{Teknik Analisis Data}

Analisa data dalam penelitian ini melalui pendekatan deskriptif, Peneliti memilih jenis penelitian ini karena peneliti bermaksud menggambarkan, menjelaskan dan mendeskripsikan kasus-kasus yang

JOMAS

Vol. 1 No. 1 Januari (2019)

Hal : $1-8$

terdapat dalam masalah penelitian ini secara kompleks. sehingga memudahkan pemahaman hasil analisis, kemudian hasilnya akan dimanfaatkan untuk membahas permasalahan yang diajukan dalam proposal penelitian ini. Dengan cara memaparkan semua data, baik data primer maupun data sekunder secara jelas. Sehingga nantinya dapat ditarik sebagai suatu kesimpulan dari berbagai masalah mengenai "Peran Serikat Perempuan Independen (SPI) Labuhanbatu dan Dinas Pemberdayaan Perempuan Dan Perlindungan Anak (DPPPA) Terhadap Korban Kekerasan Perempuan dan Anak di Kabupaten Labuhanbatu."

\section{HASIL PENELITIAN DAN PEMBAHASAN}

\section{a. Deskripsi Umum Lokasi Penelitian}

Adapun lokasi penelitian ini dilaksanakan dibeberapa instansi yang terkait pada informan yaitu sebagai berikut:

1. Deskripsi Lokasi Dinas Pemberdayaan Perempuan dan Perlindungan Anak (DPPPA) Dinas Pemberdayaan Perempuan dan Perlindungan Anak (DPPPA) berdiri semenjak adanya Peraturan Bupati Labuhanbatu Nomor 21 Tahun 2016 dan pada Tanggal 28 Oktober 2016. Yang beralamat di Jl. H. Idris Hasibuan No.2 Rantauprapat tepatnya dibelakang kantor Bupati Kabupaten Labuhanbatu.

2. Deskripsi Lokasi Serikat Perempuan Independen (SPI) Labuhanbatu

Serikat Perempuan Independen (SPI) Labuhanbatu berdiri pada tanggal 21 Oktober 2001. SPI Labuhanbatu tidak berdiri sendiri tetapi terbentuk dari Himpunan Serikat Perempuan Indonesia (HAPSARI) dimana hapsari melatih 


\section{Kajian:}

Pembelajaran PPKn

kelompok-kelompok yang menjadi organisasi diserikatnya. Yang beralamat di Jln. H. Adam Malik No. N 9 J tepatnya di Perumahan Ganda Asri.

\section{Pembahasan Hasil Penelitian}

Dari data yang peneliti peroleh dari Serikat Perempuan Independen (SPI) Labuhanbatu kekerasan terhadap perempuan dan anak ditahun 2017 yaitu 74 kasus dan ditahun 2018 yaitu 56 kasus.

Jadi dapat disimpulkan bahwa angka kekerasan yang paling tinggi terjadi pada tahun 2017 sebanyak 74 kasus kekerasan terhadap perempuan dan anak berarti adanya penurunan angka kekerasan yang terjadi di Kabupaten Labuhanbatu. Dengan adanya keberadaan Serikat Perempuan Independen (SPI) Labuhanbatu sangat membantu para korban terutama yang berada didesa dikarenakan Serikat Perempuan Independen (SPI) Labuhanbatu mempunyai posko didesa agar korban lebih mudah melapor. Dengan adanya kegiatan-kegiatan yang aktif yang dilakukan dimasyarakat.

Sedangkan data yang peneliti peroleh dari Dinas Pemberdayaan Perempuan dan Perlindungan Anak (DPPPA) Kabupaten Labuhanbatu kekerasan terhadap perempuan dan anak ditahun 2017 yaitu 71 kasus dan ditahun 2018 yaitu 61 kasus.

Jadi dapat disimpulkan bahwa angka kekerasan yang paling tinggi terjadi pada tahun 2017 sebanyak 71 kasus kekerasan terhadap perempuan dan anak berarti adanya penurunan angka kekerasan yang terjadi di Kabupaten Labuhanbatu. Dengan adanya Dinas Pemberdayaan Perempuan dan Perlindungan Anak (DPPPA) Kabupaten Labuhanbatu bisa membantu masyarakat yang menjadi korban kekerasan.

\section{KESIMPULAN DAN SARAN}

\section{A. Kesimpulan}

Dari hasil penelitian yang telah dilakukan dapat disimpulkan bahwa:

$>$ Hasil penelitian menunjukkan bahwa peran Serikat Perempuan Independen (SPI) Labuhanbatu yaitu memberikan penguatan pendampingan terhadap korban kasus kekerasan contohnya memberikan pembelaan terhadap korban, memberikan pemahaman atau pengetahuan yang luas tentang permasalahan yang dihadapi korban dan lain-lain. Sedangkan Peran Dinas Pemberdayaan Perempuan dan Perlindungan Anak (DPPPA) Kabupaten Labuhanbatu yaitu dengan cara memberikan perlindungan terhadap korban kekerasan contohnya memberikan perlindungan terhadap korban dan menginformasikan akibat yang akan diterima oleh pelaku.

\section{JOMAS}

Vol. 1 No. 1 Januari (2019)

Hal : $1-8$

$>\quad$ Dari hasil penelitian dari kedua tempat menunjukkan bahwa adanya penurunan tingkat korban kekerasan pada tahun 2018 dibandingkan pada tahun sebelumnya (2017).

$>$ Adanya faktor penyebab bahwasannya yang menjadi salah satu pemicu terjadinya kekerasan terhadap perempuan dan anak ialah faktor keluarga dan faktor perekonomian dan lain-lain. Sehingga mengakibatkan dampak fisik dan fisikis terhadap korban yang mengalami kekerasan. 
Kajian:

Pembelajaran PPKn

\section{B. Saran}

Berdasarkan kesimpulan hasil penelitian diatas, maka peneliti memberikan beberapa saran yaitu sebagai berikut:

\section{$>$ Internal}

1. Bagi peneliti sendiri untuk menambah wawasan ilmu pengetahuan tentang kekerasaan terhadap perempuan dan anak.

2. Bagi perguruan tinggi sebagai bentuk implementasi tri darma perguruan tinggi (pendidik, penelitian, pengabdian dalam melaksanakan penelitian)

3. Bagi peneliti berikutnya sebagai bahan referensi untuk usulan penelitian berikutnya.

\section{Eksternal}

1. Kepada pemerintah daerah Kabupaten Labuhanbatu agar memperhatikan perempuan dan anak yang mengalami korban kekerasan dan segera terlaksananya peraturan daerah tentang undangundang penghapusan kekerasan seksual.

2. Kepada organisasi keperempuanan Kabupaten Labuhanbatu agar memperkuat strategi keorganisasian dalam bekerjasama untuk melindungi perempuan dan anak korban kekerasan.

3. Kepada masyarakat supaya memperhatikan disekitar lingkungan terhadap perempuan dan anak yang mengalami kekerasan agar segera melapor kepada pihakpihak yang berwajib.

\section{DAFTAR PUSTAKA}

\section{BUKU}

[1] Gosita, Arif et.al. 2001. Perlindungan Terhadap Anak Korban Kekerasan
Diindonesia. Medan: Lembaga Advokasi Anak Indonesia

[2] Gultom, Maidin. 2002. Perlindungan Hukum Terhadap Anak Dan Perempuan. Bandung: PT Refika Aditama

[3] Prayitno \& Erman Amti. 2004. Dasardasar Bimbingan Konseling. Jakarta: PT Rineka Cipta

[4] Sugiyono. 2013. Metode Penelitian Pendidikan Kuantitatif Kualitatif dan $R \& D$. Bandung: Alfabeta

[5] Umri, Ali \& Imam Jauhari. 2008. Advokasi Hak-Hak Anak. Medan: Pustaka Bangsa Press

\section{JURNAL}

[6] Daulay, Harmona. 2006. Pemberdayaan Perempuan : Studi Kasus Pedagang Jamu di Geding Johor Medan. Jurnal Harmoni Sosial. Vol. 1 No.1

[7] Ruslan, Muniarti. 2010. Pemberdayaan Perempuan Dalam Dimensi Pembangunan Berwawasan Gender. Jurnal Musawa Vol. 2 No. 1

[8] Winata, Septiani Putri. 2018. Peran Lembaga Pemberdayaan Masyarakat Kelurahan Dalam Memberdayakan Masyarakat. Jurnal JOM FISIP. Vol. 5 No. 1

\section{SKRIPSI}

[9] Aristia, Nisa. 2017. Strategi Dinas Pemberdayaan Perempuan dan Perlindungan Anak Dalam Upaya Pemberdayaan Perempuan Korban Tindak Kekerasan di Kota Bandar Lampung. Skripsi. Universitas Lampung 


\section{Kajian:}

Pembelajaran PPKn

[10] Ritonga, Sakti. 2016. Analisis Sosial Pengembangan Federasi Serikat Perempuan Merdeka. Laporan Penelitian. Universitas Islam Negeri Sumatera Utara

[11] Sormin, Rahma Diana. 2017. Partisipasi Pusat Pelayanan Terpadu Pemberdayaan Perempuan dan Anak Lamban Indoman Putri Dalam Penanganan Kekerasan Terhadap Anak. Skripsi. Universitas Lampung

\section{UNDANG-UNDANG}

[12] Undang-Undang Republik Indonesia No. 35 Tahun 2014 Tentang Perubahan Atas Undang-Undang No. 23 Tahun 2002 Tentang perlindungan anak. Jakarta

[13] Undang-Undang Peraturan Daerah Kabupaten Labuhanbatu No. 5 Tahun 2015 Tentang Penyelenggaraan Perlindungan Anak

[14]http://repository.usu.ac.id/bitstream/ha ndle/123456789/56516/Chapter\%20II.pdf? $\begin{array}{lll}\text { sequence }=4 & \text { Tentang } & \text { Pengertian }\end{array}$ $\underline{\text { Perempuan }}$ 